San Jose State University

SJSU ScholarWorks

Master's Theses

Master's Theses and Graduate Research

1991

\title{
Evaluation of the reimbursable meal served to students with profoundly disabling conditions
}

Joan Giampaoli

San Jose State University

Follow this and additional works at: https://scholarworks.sjsu.edu/etd_theses

\section{Recommended Citation}

Giampaoli, Joan, "Evaluation of the reimbursable meal served to students with profoundly disabling conditions" (1991). Master's Theses. 240.

DOI: https://doi.org/10.31979/etd.y43x-m78y

https://scholarworks.sjsu.edu/etd_theses/240

This Thesis is brought to you for free and open access by the Master's Theses and Graduate Research at SJSU ScholarWorks. It has been accepted for inclusion in Master's Theses by an authorized administrator of SJSU ScholarWorks. For more information, please contact scholarworks@sjsu.edu. 


\section{INFORMATION TO USERS}

This manuscript has been reproduced from the microfilm master. UMI films the text directly from the original or copy submitted. Thus, some thesis and dissertation copies are in typewriter face, while others may be from any type of computer printer.

The quality of this reproduction is dependent upon the quality of the copy submitted. Broken or indistinct print, colored or poor quality illustrations and photographs, print bleedthrough, substandard margins, and improper alignment can adversely affect reproduction.

In the unlikely event that the author did not send UMI a complete manuscript and there are missing pages, these will be noted. Also, if unauthorized copyright material had to be removed, a note will indicate the deletion.

Oversize materials (e.g., maps, drawings, charts) are reproduced by sectioning the original, beginning at the upper left-hand corner and continuing from left to right in equal sections with small overlaps. Each original is also photographed in one exposure and is included in reduced form at the back of the book.

Photographs included in the original manuscript have been reproduced xerographically in this copy. Higher quality $6^{\prime \prime} \times 9^{\prime \prime}$ black and white photographic prints are available for any photographs or illustrations appearing in this copy for an additional charge. Contact UMI directly to order.

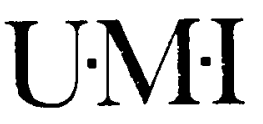




$$
\text { -... }
$$


Order Number 1347155

Evaluation of the reimbursable meal served to students with profoundly disabling conditions

Giampaoli, Joan Mary, M.S.

San Jose State University, 1991

Copyright (C)1992 by Giampaoli, Joan Mary. All rights reserved.

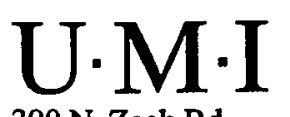

300 N. Zeeb Rd.

Ann Arbor, MI 48106 


$\ldots+\ldots-\ldots$




\title{
EVALUATION OF THE REIMBURSABLE MEAL SERVED TO STUDENTS WITH PROFOUNDLY DISABLING CONDITIONS
}

\author{
A Thesis \\ Presented to \\ The Faculty of the Department of Nutrition and Food Science \\ San Jose State University \\ In Partial Fulfillment \\ of the Requirements for the Degree \\ Master of Science \\ in Nutritional Science
}

By

Joan Giampaoli

December 1991 
APPROVED FOR THE DEPARTMENT OF NUTRITION AND FOOD SCIENCE

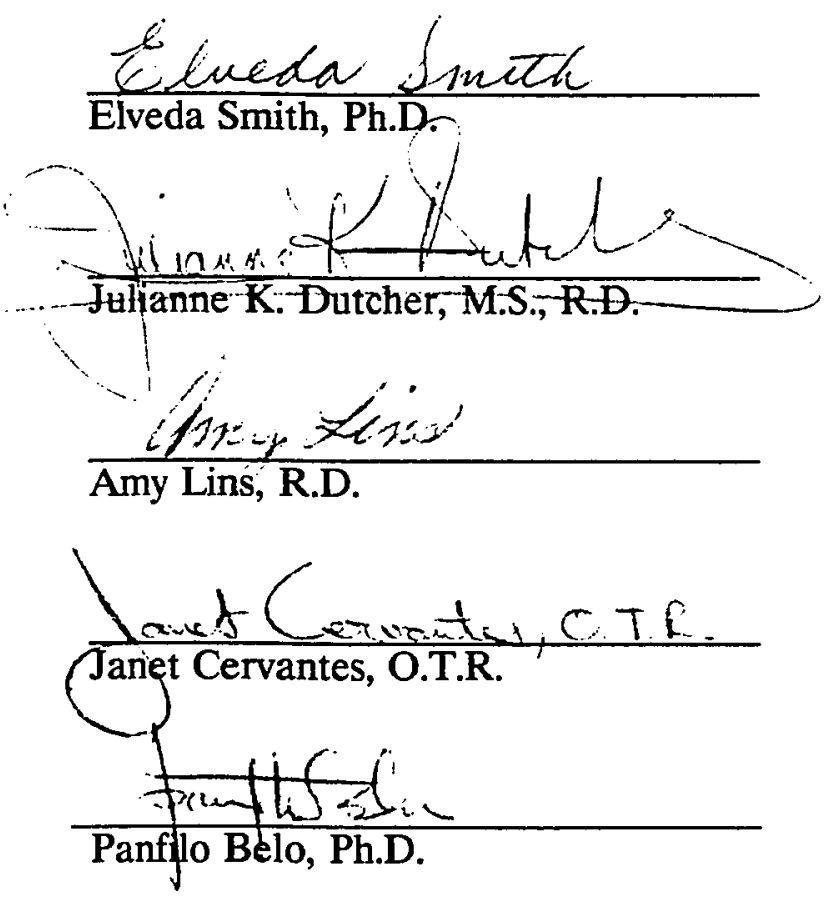

APPROVED FOR THE UNIVERSITY

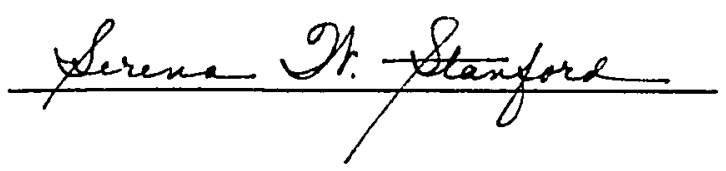




\section{ABSTRACT \\ EVALUATION OF THE REIMBURSABLE MEAL SERVED TO STUDENTS WITH PROFOUNDLY DISABLING CONDITIONS}

\section{By Joan Giampaoli}

An evaluation study was conducted to determine whether lunch meals served at a special education school site met the minimum requirements of the National School Lunch Program (NSLP) and to determine the percentage of menu items served to children with profoundly disabling conditions. Evaluation of lunch meals served to 24 profoundly disabled students was conducted for 20 school days. Data on serving sizes indicted no significant difference between portions served to the younger students (ages 5-8) in Classroom I and the NSLP requirements. Serving sizes for the older students (ages 9 and older) in Classrooms II and III differed from those of the NSLP, specifically in the meat and fruit/vegetable groups. Menu items that were texturally modified and served to the students varied between classrooms in the meat and fruit/vegetable food groups. Milk was generally not served due to its possible mucous-producing effects. 


\section{Preface}

The following is a publication style thesis, the second chapter is written in journal format according to guidelines as of January, 1991 and will be submitted to the Journal of Food Service Systems. Chapters I and III are written according to guidelines outlined in the Publication Manual of the American Psychological Association, 3rd edition, 1986. 


\section{ACKNOWLEDGEMENTS}

The author gratefully acknowledges: Gloria Giarrizzo, principal, and Amy Davis, nurse, for allowing me to conduct this study at the special education school site in San Jose, CA; Beverley Dolan, Barbara Frymer, and Lynn Robbin, special education teachers, and their aides who so kindly and openly allowed me to conduct this study in their classrooms; Amy Lins, R. D., Foodservice Director of the San Jose Unified School District, whose invaluable guidance helped clarify for me the many aspects of the National School Lunch Program and whose interest in this topic helped me create and conduct this study; Janet Cervantes, O.T.R., for her expertise and assistance in educating me about children with profoundly disabling conditions; Dr. Bethany Shifflett, for analyzing the data collected from this study; Anna Grayson, for her many hours spent typing this manuscript and for her consistently cheerful attitude; Dr. Elveda Smith, for her great care and dedication in editing and correcting this manuscript; Dr. Panfilo Belo, for his assistance in developing the data collection methods used in this study; and Mrs. Julianne K. Dutcher, for presenting me with the idea of this study and whose guidance and constant support helped me complete it. I am grateful to each one of you and am thankful for your unique and vital contributions. 
List of Tables

\section{CHAPTER}

1 INTRODUCTION AND REVIEW OF LITERATURE . . . . . . . 1

Introduction $\ldots \ldots \ldots \ldots \ldots \ldots \ldots \ldots \ldots \ldots \ldots \ldots \ldots \ldots$

Review of Literature $\ldots \ldots \ldots \ldots \ldots \ldots \ldots \ldots \ldots \ldots \ldots \ldots \ldots$

Public Law $94-142 \ldots \ldots \ldots \ldots \ldots \ldots \ldots \ldots \ldots \ldots \ldots$

Legislative History $\ldots \ldots \ldots \ldots \ldots \ldots \ldots \ldots \ldots \ldots$

Major Components of Public Law 94-142 .......... 9

Right to a Free and Appropriate Public Education ...... 9

Nondiscriminatory Evaluation $\ldots \ldots \ldots \ldots \ldots \ldots \ldots, 10$

Procedural Due Process ............... 10

Individualized Education Program $\ldots \ldots \ldots \ldots \ldots \ldots, 11$

Least Restrictive Environment ............. 12

The Child with Developmental Disabilities ........... 14

The Population $\ldots \ldots \ldots \ldots \ldots \ldots \ldots \ldots \ldots \ldots \ldots \ldots \ldots$

Feeding Abnormalities of Children with

Developmental Disabilities ................. 16

Nutritional Concerns ..................... 19

Energy Intake $\ldots \ldots \ldots \ldots \ldots \ldots \ldots \ldots \ldots \ldots \ldots, 20$ 
Iron Deficiency Anemia $\ldots \ldots \ldots \ldots \ldots \ldots \ldots \ldots, 23$

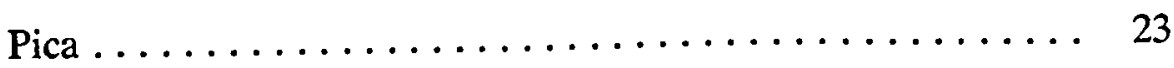

Vitamin D Deficiency .................. 24

Food Management $\ldots \ldots \ldots \ldots \ldots \ldots \ldots \ldots \ldots \ldots \ldots \ldots \ldots \ldots \ldots$

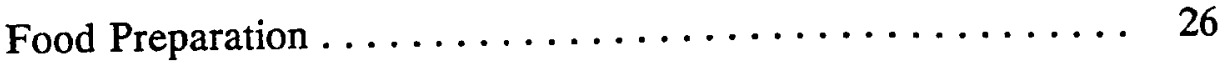

Pureed Foods $\ldots \ldots \ldots \ldots \ldots \ldots \ldots \ldots \ldots \ldots \ldots \ldots \ldots \ldots$

Intermediate or Soft Foods ................ 28

Liquid Items . . . . . . . . . . . . . . . 29

Utensil Management ..................... 29

Technique Management $\ldots \ldots \ldots \ldots \ldots \ldots \ldots \ldots \ldots, 31$

Positioning $\ldots \ldots \ldots \ldots \ldots \ldots \ldots \ldots \ldots \ldots \ldots \ldots \ldots \ldots \ldots$

Oral/Jaw Control ..................... 32

Presentation of Food $\ldots \ldots \ldots \ldots \ldots \ldots \ldots \ldots \ldots, 34$

The National School Lunch Program ............. 35

Training Programs $\ldots \ldots \ldots \ldots \ldots \ldots \ldots \ldots \ldots \ldots \ldots \ldots$

Liability Issues $\ldots \ldots \ldots \ldots \ldots \ldots \ldots \ldots \ldots \ldots \ldots \ldots \ldots \ldots \ldots \ldots$

2 JOURNAL ARTICLE $\ldots \ldots \ldots \ldots \ldots \ldots \ldots \ldots \ldots \ldots \ldots \ldots \ldots \ldots$

ABSTRACT $\ldots \ldots \ldots \ldots \ldots \ldots \ldots \ldots \ldots \ldots \ldots \ldots \ldots \ldots \ldots \ldots \ldots \ldots \ldots$

INTRODUCTION $\ldots \ldots \ldots \ldots \ldots \ldots \ldots \ldots \ldots \ldots \ldots \ldots \ldots \ldots \ldots \ldots$ 
Page

METHODS AND MATERIALS $\ldots \ldots \ldots \ldots \ldots \ldots \ldots \ldots \ldots, 48$

Subjects $\ldots \ldots \ldots \ldots \ldots \ldots \ldots \ldots \ldots \ldots \ldots \ldots \ldots \ldots \ldots \ldots \ldots \ldots$

National School Lunch Program Requirements ............ 49

Data Collection Method $\ldots \ldots \ldots \ldots \ldots \ldots \ldots \ldots \ldots, 50$

Comparison of Lunch Meals Served to the NSLP Requirements . . 51

Textural Modification of Menu Items $\ldots \ldots \ldots \ldots \ldots \ldots \ldots \quad 51$

Menu Items Served $\ldots \ldots \ldots \ldots \ldots \ldots \ldots \ldots \ldots \ldots \ldots \ldots \ldots \ldots \ldots$

RESULTS AND DISCUSSION $\ldots \ldots \ldots \ldots \ldots \ldots \ldots \ldots \ldots, 52$

Comparison of Lunch Meals Served to the NSLP Requirements . . . . 52

Textural Modification of Menu Items $\ldots \ldots \ldots \ldots \ldots \ldots \ldots \ldots \quad 53$

Menu Items Served $\ldots \ldots \ldots \ldots \ldots \ldots \ldots \ldots \ldots \ldots \ldots \ldots \ldots$

CONCLUSION $\ldots \ldots \ldots \ldots \ldots \ldots \ldots \ldots \ldots \ldots \ldots \ldots \ldots \ldots \ldots \ldots \ldots \ldots$

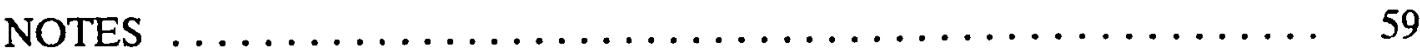

ACKNOWLEDGEMENTS $\ldots \ldots \ldots \ldots \ldots \ldots \ldots \ldots \ldots \ldots, 60$

REFERENCES $\ldots \ldots \ldots \ldots \ldots \ldots \ldots \ldots \ldots \ldots \ldots \ldots \ldots \ldots \ldots \ldots \ldots \ldots$

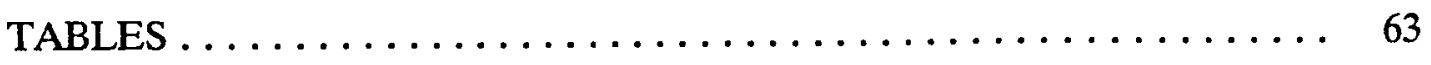

3 SUMMARY, LIMITATIONS, RECOMMENDATIONS . . . . . . . 66

Summary $\ldots \ldots \ldots \ldots \ldots \ldots \ldots \ldots \ldots \ldots \ldots \ldots \ldots \ldots \ldots \ldots \ldots, 66$

Limitations ......................... 67

Recommendations $\ldots \ldots \ldots \ldots \ldots \ldots \ldots \ldots \ldots \ldots \ldots \ldots, 67$

viii 
Page

REFERENCES ........................... 69 
List of Tables

Tables

Page

I. Feeding Abnormalities of the Child with . . . . . . . . . . 18 Developmental Disabilities

II. The National School Lunch Program Minimum Requirements . . . . . 37

1. Demographic Data on Subjects ................. 63

2. Lunch Meals Served that Met the National School Lunch

Program Minimum Requirements . . . . . . . . . . . . . . . 64

3. Textural Modification of Menu Items and Menu Items Served . . . . 65 


\title{
CHAPTER I
}

\section{INTRODUCTION AND REVIEW OF LITERATURE}

\author{
Introduction
}

The Education for All Handicapped Children Act, Public Law 94-142, mandates that public schools provide appropriate education in the least restrictive setting for all handicapped children, ages three through twenty-one years (Gunther \& Troftgruken, 1982). As a result of this legislation, many handicapped children are enrolled in public schools and are participating in the National School Lunch and School Breakfast Programs. Given their special nutritional needs, many of these children may need assistance to meet their dietary needs (Horsley \& Allen, 1989).

The National School Lunch Act stipulates a meal pattern that the schools must follow to receive reimbursement for meals served to all children including handicapped children (Gunther \& Troftgruken, 1982). Improvement in the overall nutrition of school children is the goal of school foodservice. School lunch and breakfast programs contribute by offering a meal of nutritious foods, based on the four major food groups, which are well-prepared and served (Woodburn \& Fitch, 1978). Although schools are not required to provide special diets for any student, school districts, to meet the nutritional needs of the handicapped children, can do so, and, if state and federal requirements for the meals are met, the meals are claimed for reimbursement from the child nutrition program (Gunther \& Troftgruken, 1982). 
The Rehabilitation Act of 1973 is cited as a mandate for the rights of all handicapped persons to participate in the least restrictive environment (Wehman et al., 1985). Section 504 of the Rehabilitation Act of 1973 states that "No otherwise qualified handicapped individual in the United States... shall, solely by reason of his handicap, be excluded from the participation in, be denied the benefits of, or be subjected to discrimination under any program or activity that is receiving federal financial assistance" (Savage, 1977, p. 23).

In meeting the special nutritional needs of children with disabling conditions, certain obstacles exist. Adequate nutrition is essential for these children to reach their full developmental potential (Caldwell, 1982). It has been well documented that energy intake is lower for these children due to retarded neuromuscular development which impedes their ability to consume food (Dietz \& Bandini, 1989; Kalisz \& Ekvall, 1984; Pipes \& Glass, 1989). Lowered energy intake increases the risk of malnutrition, weight loss, growth retardation, and diminished function (Dietz \& Bandini, 1989; Riordan et al., 1984). According to Crump (1987), factors contributing to malnutrition are lack of nutrition education and inappropriate foods. School lunches may not provide foods which the child can eat. However, the provisions of the Rehabilitation Act of 1973 indicate that no handicapped individual in the United States (U.S.) shall be subject to discrimination by or be denied the benefit of any program or activity that is federally funded (Savage, 1977). 
Children with Developmental Disabilities

The report of the 1982 Surgeon General's Workshop on Children with Handicaps and their families states that "Of the unmet health care needs of American children, the needs of children with handicaps are those most deeply felt" (American Dietetic Association Position Statement (ADAPS), 1989, p. 1133). The American Dietetic Association (ADA) reaffirms its position that appropriate nutrition services should be available to all children, and children with developmental disabilities must have the opportunity to achieve their potential in all areas of development. Despite improvements in meeting their complex needs, major gaps in services exist, particularly those related to nutritional support, a crucial factor needed for these children to achieve their maximum potential (ADAPS, 1989). Therefore, a need exists to determine whether lunch meals served to children with profoundly disabling conditions meet their unique nutritional requirements. The purposes of this study were to evaluate the following research questions:

1. Do lunch meals served meet the minimum requirements of the National School Lunch Program (NSLP)?

2. Do menu items on the lunch meal require textural modification?

3. What percentage of menu items offered on the lunch meal are served to children with profoundly disabling conditions? 
Children with Developmental Disabilities

\section{Review of Literature}

\section{Public Law 94-142}

\section{Legislative History}

In the 1950 s and 1960 s, there developed an increased recognition and respect for the human dignity of all citizens regardless of individual differences (Stainback et al., 1989). The most notable early landmark of this era was the 1954 Brown v. Board of Education decision in which Chief Justice Earl Warren ruled that "separate is not equal" (Stainback et al., 1989, p. 7). The chief advocate for the defense in the 1954 decision, John W. Davis, argued that, if segregation for black children was unconstitutional, surely it will be found that segregation of children defined as disabled is also unacceptable (Stainback et al., 1989). While this had immediate impact in reducing exclusionary policies towards blacks and other racial and ethnic minorities, it also increased review of exclusionary policies for students with disabilities (Stainback et al., 1989).

Efforts to push for protection of rights in education were advanced by two court cases in the early 1970s. One case, still a landmark in the area of public education for the handicapped, was the Pennsylvania Association for Retarded Children (PARC) v. Commonwealth of Pennsylvania (Percy, 1989). The plaintiffs, acting on behalf of 14 mentally retarded students and others of similar condition, brought a class action suit against the state of Pennsylvania, arguing that their due process and equal protection rights had been violated by state laws which: 
1. included no provisions for hearings before a retarded child was excluded from public education,

2. assumed that retarded children are uneducable, and

3. arbitrarily and capriciously denied retarded children the right to an education (Percy, 1989).

The litigation was settled in 1972 , and the state agreed that "it is the Commonwealth's obligation to place each mentally retarded child in a free public program of education and training appropriate to the child's capacity" (Percy, 1989, p. 56).

In a second case, Mills v. Board of Education of the District of Columbia, parents and guardians of seven retarded children sued the Board of Education, charging that the defendant denied these children access to publicly supported education (Percy, 1989). The district court ultimately ruled in favor of the plaintiffs and ordered, among other stipulations, that "the District of Columbia shall provide each child of school age a free and suitable publicly-supported education regardless of the degree of the child's mental, physical, or emotional disability or impairment. Furthermore, defendants shall not exclude any child resident in the District of Columbia from such publicly-supported education on the basis of a claim of insufficient resources" (Percy, 1989, p. 57). The Mills case also extended protection to all forms of disability, not just mental retardation, and stated that lack of funds was not a sufficient rationale to justify not providing 
equal and appropriate education for handicapped children (Percy, 1989).

By the mid 1970s, Congress was favorable to the development of stronger efforts to ensure that education of handicapped children be tailored to individual needs. The Pennsylvania and the Mills cases served to strengthen legal foundations for handicapped children to receive a free and appropriate education, based on due process and equal protection rights concluding: "The overriding implication of 1971-72 court decisions is the right of equal access to education opportunity for all children" (Percy, 1989, p. 57).

On November 29, 1975, due to pressure from parents, courts, and legislatures, President Gerald Ford reluctantly signed S6, a federal law guaranteeing a "free, appropriate public education" to all handicapped children (Savage, 1977). The United States Code (1975) states the following purpose of Public Law (PL) 94-142: "It is the purpose of this Act to assure that all handicapped children have available to them... a free appropriate public education which emphasizes special education and related services designed to meet their unique needs, to assure that the rights of handicapped children and their parents or guardians are protected, to assist states and localities to provide for the education of all handicapped children, and to assess and assure the effectiveness of efforts to educate handicapped children" (p. 775).

Several problems with the public education system and the education of the handicapped, as Congress initially saw them, which led to the passage of PL 
Children with Developmental Disabilities

94-142 were that:

1. there are more than eight million handicapped children in the U.S. today;

2. the special education needs of such children are not being fully met;

3. more than half of the handicapped children in the U. S. do not receive appropriate educational services;

4. one million of the handicapped children in the U.S. are excluded entirely from the public school system and will not go through the education process with their peers;

5. there are many handicapped children... particularly in regular school programs... whose handicaps are undetected;

6. because of the lack of adequate services within the public school system, families are often forced to find services outside the public school system - often at great distance from residence and at their own expense;

7. developments in the training of teachers and in diagnostics and instructional procedures have advanced to the point that, given appropriate funding, state and local educational agencies can and will provide effective special education;

8. state and local education agencies have a responsibility to provide education for all handicapped children, but present financial resources are inadequate; and 
9. it is in the national interest that the federal government assist state and local efforts to provide programs to meet the education needs of handicapped children in order to assure equal protection under law (Savage, 1977). For these children (an estimated six to eight million) and their parents, the passage of PL 94-142 represented the culmination of a long and frustrating battle to gain a right that other children gained at birth, the right to an education (Savage, 1977).

Public Law 94-142, called the "Education For All Handicapped Children Act," provides for the educational rights of the handicapped and explains procedures for the distribution of federal resources in establishing and maintaining special education programs. States must provide evidence that they are meeting the intent of the law in helping handicapped children receive appropriate education (Wood, 1989). The major components of PL 94-142 which have a direct effect on the handicapped child are:

1. the right to a free and appropriate public education,

2. nondiscriminatory evaluation,

3. procedural due process,

4. an individual education program (IEP), and

5. a least restrictive environment (LRE) (Wood, 1989). 
Children with Developmental Disabilities

Major Components of Public Law 94-142

Right to a Free and Appropriate Public Education

The Education for All Handicapped Children Act mandates publicly supported education for all handicapped children aged three to seventeen (by September 1, 1978) and aged three to twenty-one (by September 1, 1980) - unless it is "inconsistent" with current state laws (Savage, 1977). According to the U.S. Code of 1975, the term "free appropriate public education" in PL 94-142 means special education and related services which:

1. have been provided at public expense, under public supervision and direction, and without charge;

2. meet the standards of the state educational agency;

3. include an appropriate preschool, elementary, or secondary school education in the state involved; and

4. are provided in conformity with the IEP.

The term "related services" means transportation and such developmental, corrective, and other supportive services (including speech pathology and audiology, psychological services, physical and occupational therapy, recreation, and medical and counseling services)... as may be required to assist a handicapped child to benefit from special education.

Although this fundamental freedom has always been afforded to the regular student, the handicapped student was denied this right prior to 1975. 
Since 1975, handicapped students can now attend neighborhood schools and receive necessary services to accommodate regular education. Special students are no longer denied the right to attend school, and support is provided to ensure that they receive an education comparable to regular students (Wood, 1989).

\section{Nondiscriminatory Evaluation}

In an attempt to eliminate errors in the classification and placement of children who have suspected handicaps, the law requires nondiscriminatory evaluation of students. The fundamental intent of this provision is to eliminate discrimination based on cultural background, race, or handicapped conditions (Wood, 1989). According to the law, the evaluation process works "to determine whether a child is handicapped and the nature and extent of the special education and related services that the child needs. The term means procedures used selectively with an individual child and does not include basic tests administered to or procedures used with all children in a school, grade, or class" (Wood, 1989, p. 9).

\section{Procedural Due Process}

Section 615 of PL 94-142 establishes strict procedural safeguards for handicapped children and their parents. The rights of parents or guardians "shall include but not be limited to" the right to:

1. examine all relevant records with respect to identification, evaluation, and educational placement; 
Children with Developmental Disabilities

2. obtain an independent educational evaluation of their child;

3. "present prior notice" - in their native language - of any proposed action such as a change in the identification, evaluation, or placement of the child; and

4. "present complaints" about any action.

If parents or guardians have complaints, they have a right to an "impartial due process hearing" with a hearing officer who is not an employee of any state or local educational agency. "Any party aggrieved" by the result of the hearing has a right to appeal to the state for an impartial review (Wood, 1989). If a party is still not satisfied, a civil action may be pursued in state or federal court (Savage, 1977). Both parents and school authorities also have the right to an appeal (Wood, 1989).

\section{Individualized Education Program}

The individualized education program requires that school systems provide a written statement for each handicapped child, indicating the child's present state of performance, future learning objectives, educational services needed, and criteria for yearly assessment (Percy, 1989). The program is a yearly assessment agreement used by parents and school personnel (Wood, 1989). The law requires that an IEP be developed annually for each handicapped student; there are no provisions or guidelines regarding more frequent review (Wehman et al., 1985). 
Children with Developmental Disabilities

\section{Least Restrictive Environment}

One of the basic principles of the 1975 education law for handicapped children is the right of each child to be educated in the "least restrictive environment (alternative)" setting. It emphasizes the importance of learning in as normal an environment as possible. PL 94-142 states that children should be removed from the mainstream of school life only if it really is not possible for them to function in a regular class (even with extra assistance). When a child is in a separate program, every effort should be made to provide experiences for give-and-take with non-handicapped peers (Gearheart \& Weishahn, 1980).

The least restrictive environment or setting denotes a circular array of delivery systems. Restrictive refers to the degree of interaction with non-handicapped children available in a particular educational setting. The needs and strengths of the child largely determine the level of placement and services most appropriate as well as the setting into which the child best fits (Savage, 1981).

The least restrictive environment for the child is determined by the IEP team (occupational therapist, teacher, doctor, etc.) based on the assessment of the student, observations, and progress in a variety of settings. The placement in a setting is temporary, and the IEP is reviewed annually to update progress. According to Steve Johnson (1990), the placement in a setting should be thought of as a curricular array of options, and the student can be placed, or moved, from 
Children with Developmental Disabilities

one setting to another based on needs. No value judgement, such as moving up or down, is attached to the settings. The child is placed where needs are best met at that stage of development.

The least restrictive environment covers a wide variety of alternatives, and it is recomme:ided that placement should be made on the basis of individual needs. For some, it means learning in a regular classroom with the help of the resource teacher or with other special kinds of aid. For others, it may mean spending most of the day in separate classrooms, with as much opportunity as possible to participate in regular school activities. For a few, it may be necessary to live and learn in a residential setting, but close to home, with as much contact with the real world as possible (Gearheart \& Weishahn, 1980).

In a personal conversation with Lalite Ray (1991), four placement options in California were cited:

1. Designated Instruction Services: This is known as "mainstreaming or the full inclusion model" for placement in which the handicapped child is in the regular classroom all day with special services available such as speech, occupational therapy, etc.

2. Resource Specialist Program: The child is in a special class but spends part of the day with non-handicapped peers. Most of the learning disabled are placed in this type of setting.

3. Special Day Classes: The children are taught in a school building but 
Children with Developmental Disabilities

in distinctly separate classes.

4. Non-public or Private Schools: These schools are supported by private industry or agencies. He stated that the education of the child will still be funded by the government if they are placed in the setting by a government program.

Child count data compiled by the U.S. Office of Special Education and Rehabilitative Services indicate that there has been little change in the kinds of environment into which handicapped children are placed. Since 1975 , the majority (93\%) of the pupils who are classified as handicapped attend regular public schools. More than two-thirds also receive most of their instruction in regular classes along with non-handicapped age-mates. Groups that are most likely to be taught in special schools or other facilities are the deaf-blind (47\%), the multihandi apped (33\%), and the orthopedically impaired (34\%) (Congressional Report, 1985). In 1985, Danielson and Bellomy reported that $94 \%$ of the children with handicaps are educated in regular school buildings. This means that 225,000 , or $6 \%$, of all students with handicaps are educated in programs outside the school setting.

\section{The Child with Developmental Disabilities}

\section{The Population}

In the not so distant past, many premature infants did not survive, but improvements in technology and medical care have increased the survival of premature infants (Lucas, 1989). However, the survival of these infants has 
Children with Developmental Disabilities

resulted in some individuals who have unique metabolic disorders and who require specific medical and nutritional intervention (Lucas, 1989).

According to the Select Panel of the Promotion of Child Health (Caldwell, 1982), some type of chronic impairment affects 10 million children in the U.S. In a Rand Corporation report, it was estimated that $2,883,000$ children have sensory disorders (hearing, vision, and speech), 1,676,000 have other crippling conditions, and 50,000 are multiply handicapped (Caldwell, 1982). Also, two to three million children in the U.S. suffer from mental retardation (Caldwell, 1982).

During the last 20 to 30 years, the estimated prevalence of chronic illness and handicapping conditions in the school age population has increased. Approximately $90 \%$ of children with 22 of the most common childhood disorders now survive to adulthood (ADAPS, 1989). Estimates of the prevalence of chronic disorders generally range between 10 and $20 \%$ of the child population. Likewise, nearly $4 \%$ of all children under 17 years of age have major limitations in activity which appear to result from chronic conditions.

Prevalence rates for severely and profoundly mentally retarded individuals vary. Designating those individuals with an intelligence quotient (IQ) less than 50 as severely retarded, the prevalence rates are 4 per 1000 persons. More conservative estimates put the prevalence rates at 0.8 per 1000 . For profoundly retarded individuals, those having an IQ of 25 or less, the estimates are at 0.5 per 1000 , or 1.3 per 1000 for both groups (Blacher, 1984). 
Children with Developmental Disabilities

The term, severely handicapped, describes a wide range of children including those who are autistic, severely emotionally disturbed, developmentally disabled, and severely or profoundly retarded. While the Association for the Severely Handicapped (ASH) currently has no official definition for this population, the term, severely handicapped, generally includes not only those individuals who are severely and profoundly mentally retarded, but also those whose handicap (e.g., emotional disturbance, health impairment, orthopedic impairment, blindness, deafness, etc.) is so severe as to render them functionally retarded. Based on this definition, severely handicapped individuals represent a heterogenous group with respect to central nervous system (CNS) functioning, physical growth and development, and adequacy of behavioral repertoire (Blacher, 1984).

\section{Feeding Abnormalities of Children with Development Disabilities}

The child with a developmental disability may have any one of a number of deficits in neurological development that could result in impairments of intelligence, motor, language, and personal-social skills. The causes of the developmental disabilities are numerous and varied, with the primary insult theorized to occur sometime during the pre- or postnatal period (Howard, 1981).

For years, the special nutritional needs of developmentally disabled children have been overlooked, and their poor growth patterns have usually been ascribed to neurological deficits with little thought given to the possibility that the 
child was malnourished. Children with CNS dysfunction often demonstrate abnormal feeding behavior with poor sucking ability; therefore, small amounts of food have been consumed from birth. This behavior serves to compromise nutritional status at a critical time of brain growth and carries with it the distinct possibility of further developmental compromise of an already disabled child (Howard, 1981). Some feeding abnormalities that children with developmental disabilities exhibit are presented in Table I.

Developmentally delayed children require the same nutrients as any individual (Pipes \& Glass, 1989). There are, however, no dietary standards applicable to groups of developmentally delayed children (Pipes \& Glass, 1989). According to Pipes and Glass (1989), some nutritional problems of children with developmental disabilities are:

1. abnormal motor patterns that affect the child's ability to consume food;

2. gagging, vomiting, or rumination;

3. inability or unwillingness of the child to finger-feed or self-feed;

4. refusal of the child to consume specific foods or groups of foods;

5. refusal of the child to progress in feeding behavior when developmentally ready;

6. slow growth in length and lack of appropriate weight gain;

7. excessive weight gain in relation to gains in length;

8. lack of appetite; 


\section{Table I}

Feeding Abnormalities of the Child with Developmental Disabilities

1) an exaggeration of a normal feeding skill:
a) tonic bite reflex
b) tongue thrust
c) tongue retraction
d) hyperactive gag reflex

2) a delay in the normal progression of feeding skills:

a) inability to grasp food or to finger feed

b) difficulty in cup drinking

c) difficulty using a spoon

3) poor coordination of jaw, lips and tongue for swallowing and chewing:
a) poor lip closure
b) poorly controlled tongue movements
c) poor chewing pattern

4) inability to sit independently in an upright position:
a) poor head control
b) poor trunk control
c) involuntary movements

5) problem behaviors at mealtime:
a) mouth stuffing
b) rumination (food from stomach to mouth)
c) food refusal
d) self-abusive behavior
e) defensiveness during feedings
f) inability to stay on task
g) prolonged feeding periods

Note. Adapted from Nutrition Management of the Handicapped and Chronically Ill School Age Children (p. 47) by J. W. Horsley, E. R. Allen, and P. A. White, 1990, Beltsville, MD: United States Department of Agriculture.

Grant No. MC55103305. 


\section{Children with Developmental Disabilities}

9. excessive appetite;

10. obesity;

11. bizarre feeding patterns;

12. pica;

13. iron deficiency anemia;

14. constipation;

15. limited fluid intake;

16. food allergies;

17. limited attention span at mealtime; and

18. disruptive behavior at mealtime.

\section{Nutritional Concerns}

Adequate nutrition is essential for the growth and health of a handicapped child. In fact, nutrition may be the most important factor in the survival of some handicapped children (Caldwell, 1982). Optimal nutrition is essential for children to achieve their physical and developmental potential. In addition, some handicapped and developmentally delayed children experience difficulties in consuming an adequate food intake, while others, because of inactivity or psychosocial factors, consume excess energy and become obese (ADAPS, 1981). Retarded neuromuscular development manifested as difficulty in sucking, swallowing, lip closure, prehension, etc. affects the intake of food (Kalisz \& Ekvall, 1984). Although food consumption of handicapped children has not been 
Children with Developmental Disabilities

studied, data are available on some nutritional concerns of these children. A diagnostic and evaluation center reported that the most frequent nutrient inadequacies were ascorbic acid, fluoride, and high-quality protein (Pipes \& Glass, 1989). Another center studied 500 patients and reported that $21 \%$ were overweight, $8 \%$ had bizarre feeding habits, $13 \%$ had inadequate intake, and $31 \%$ had feeding problems (Pipes \& Glass, 1989).

\section{Energy Intake}

Energy intakes of children with developmental disabilities are generally lower than age-matched controls. According to Dietz and Bandini (1989), deficits in either protein or energy may restrict growth, increase susceptibility to infection, or impair cognitive development.

Children with reduced energy intake conserve energy for the fixed energy requirements, such as basal metabolic rate. Discretionary activity appears to be the most flexible component of energy expenditures. Discretionary activity includes the energy that children use to explore, interact, and elicit stimulation (Dietz \& Bandini, 1989). These researchers theorized that activity may provide the earliest adjustment to undernutrition, which impairs immune function and cognitive development. Therefore, recognition of inadequate energy intake in children with existing handicaps is crucial.

Children who consume insufficient amounts of food are at high risk for a number of problems, including excessive weight loss, lethargy, malnutrition, 
Children with Developmental Disabilities

diminished function, and growth retardation (Riordan et al., 1984). Poor nutrition weakens a child who is already at a nutritional disadvantage when compared with a normal child (Alakija, 1988). The causes of malnutrition in school-aged children have been identified by Crump (1987):

1. Lack of nutrition education can result in poor food choices.

2. Lack of communication skills limits what the child can express about his or her feelings of pain, hunger, or thirst. Rejection of food may occur because it is too hot or salty or the child dislikes the taste rather than because the child is not hungry.

3. Poor motor coordination can make feeding so difficult that a limited mealtime or fatigue does not allow the child to get enough food each meal.

4. Energy (kcal) and nutrient needs may be increased because of malabsorption or increased expenditure due to cardiac malfunction, athetosis, infection, or other stress.

5. Spillage is often disregarded; more food may end up on the outside rather than inside the child.

6. Bizarre eating habits can result from indulgence by family members who feel that giving their child freedom in food choices compensates for limitations in other abilities.

7. Absence of appetite can be caused by CNS.

8. Hyperactivity increases a child's energy expenditure and decreases 
Children with Developmental Disabilities

attention span so that mealtime is interrupted frequently.

9. School lunches may not provide foods that the child can eat.

\section{Constipation}

Fluid consumption by handicapped children is another concern. Most children with handicaps fall short of the recommended $1.5 \mathrm{ml} / \mathrm{kcal}$. This leads to problems of constipation. Because thin liquids are difficult for these children to consume, this problem can be hard to resolve. The use of additional fiber-rich fruits and vegetables, incorporated into the diet until sufficient fluid intake is achieved, is one solution (Morris et al., 1990). To increase fluid consumption, Wellman et al. (1988) recommended using foods that become liquid at room temperature and serving foods which contain large amounts of fluid.

Along with fluid consumption, another nutritional problem which can be identified in children with handicaps, is the problem of constipation. This is usually associated with a lack of mobility and/or insufficient intake of liquids and fibrous food (Kalisz \& Ekvall, 1984). According to Horsley et al. (1990), constipation may be caused by one or a combination of factors including:

1. lack of dietary fiber and fluids,

2. abnormal muscle tone,

3. decreased or insignificantly altered physical activity level,

4. irregular bowel patterns or toileting habits,

5. behavioral problems such as anxiety or tiredness which may interfere 
Children with Developmental Disabilities

with regular bowel patterns,

6. medical conditions causing lack of sensation in the rectum and the child cannot feel that the rectum is full, and

7. side effects of medication.

The dietary recommendations to prevent constipation are to increase fiber and fluid in the diet. If a child is unable to manage high fiber foods, unprocessed wheat bran may be added to the diet by adding it to foods. Wheat bran should be introduced in small amounts and gradually increased in the diet (Horsley et al., 1990).

\section{Iron Deficiency Anemia}

Iron is a nutrient whose intake is limited even in the diets of normal children. Results of studies have generally indicated that low intakes of dietary iron are especially a problem in handicapped children. It is suggested that mothers prolong the use of soft, milk-based foods and, as a result, serve a diet characteristically low in iron-rich foods (Caliendo et al., 1982). Handicapped children often show evidence of low dietary iron intakes, as well as feeding problems related to lower iron intakes, suggesting that this particular group may be at a greater risk for developing iron deficiency anemia than is the general population of children (Caliendo et al., 1982).

Pica

Pica, an eating disorder commonly found in institutionalized retarded 
Children with Developmental Disabilities

individuals, is also found in the free-living population and results in malabsorption of zinc and iron. Sanford, Smith, and Huber (Pipes \& Glass, 1989) found that individuals with pica had low plasma levels of zinc and iron although they received adequate dietary intake of these minerals.

\section{Vitamin D Deficiency}

Anticonvulsants, such as dilantin and phenobarbital, may precipitate deficiencies in folacin and possibly vitamin B12 and abnormalities in vitamin D and bone metabolism (ADAPS, 1981). Evidence of vitamin D deficiency was found in both institutionalized patients and outpatients treated with anticonvulsant drugs to control seizures for longer than six months (Pipes \& Glass, 1989). Osteomalacia was observed in $70 \%$ of institutionalized patients and rickets in 7 to 8\%. Pathologic fractures are not uncommon. According to Dietz and Bandini (1989), these disorders are more prevalent in nonambulatory patients with limited exposure to sunlight.

\section{Food Management}

The Biblical quotation, "Man does not live by bread alone," applies very literally to children. When a baby is developmentally disabled, poor nutrition and feeding difficulties further impede growth and development. On the other hand, sound nutrition and successful feeding enhance well-being and foster higher levels of physical and mental attainment (Connor et al., 1978). In the former situation, children are likely to be poorly nourished. Many reasons are cited to explain the 
Children with Developmental Disabilities

reasons that the developmentally disabled infant is prone to undernourishment and malnutrition. Problems associated with feeding include difficulty in sucking and/or swallowing, hyperactivity or weakness resulting in poor intake of food, and ineffective parenting (Connor et al., 1987).

The development of poor eating behavior is a problem encountered frequently among students in special education programs (Crump, 1987). For example, a child with cerebral palsy may have structural or functional damage of the oral mechanism. Spasticity defers the development of chewing and swallowing, and special training of the caregiver is often required. Adequate nutrition and speech development are the goals of individual education programs which include feeding training (Crump, 1987). If nutritional goals are ignored, delayed growth, weight loss, and poor health occur. In addition, the child continues to accept only smooth, cooked foods, and thereby misses the pleasure of tasting a wide variety of solid foods (Crump, 1987).

A frequent problem in the older infant and child with feeding problems is food inappropriate to the level of feeding and the oral competence. Food varies in taste, temperature, texture, and consistency. Food management involves gradually increasing tolerance by changing one domain of the food offered at a time. Adding finely chopped carrots to a thickened, pureed food introduces a second texture and size that can gradually be increased (Crane, 1987). Semi-solid foods, such as a cookie, are good for biting and swallowing because they are a 
Children with Developmental Disabilities

dissolvable solid; they soften in the mouth. Examples of semi-solid foods are cookies, crackers, Cheerios, etc. (Down, 1990). These semi-solid foods can be finger fed to the side of the child's mouth to fall between the molar teeth or gum ridges. In this position, if a chewing reflex exists, the child crunches on the puff. It breaks down and quickly disintegrates giving high kinesthetic feedback as well as loud auditory crunch (Crane, 1987).

If a child stays on a pureed diet longer than necessary, interest in foods fades (Wellman et al., 1988), or there is an increased refusal to accept solid foods. When signs of rotary chewing occur, a child is ready to progress to chopped foods. Practice is necessary to develop good chewing skills (Wellman et al., 1988).

The change from strained food and liquids to a greater variety of textures is a slower process in handicapped than in non-handicapped children. It is important to encourage this process as soon as the child is ready (Wellman et al., 1988). Chopped, ground, or blended foods are better than strained foods. They provide chewing practice and promote normal bowel movements due to intake of fiber. As the child learns to use the tongue, mouth, and throat muscles, chopped solid foods replace blended ones (Wellman et al., 1988). Although the need for food management is a major part of feeding therapy, it is least recognized by hospital or residential caterers (Crane, 1987).

Food Preparation

Children who have difficulty feeding themselves need to have the food 
Children with Developmental Disabilities

modified since the consistency of food affects the ability to get food from the plate onto a spoon and into the mouth (Gunther \& Troftgruken, 1982). The level of the child's eating ability is also a determining factor in the selection of the form of the food served. Children bottle-fed formula or spoon-fed pureed foods since birth have not developed sufficient chewing skills, and hard foods such as a taco or celery sticks are questionable menu items. Children who choke on small hard pieces of food also require soft foods until they learn proper swallowing techniques and control of the gag reflex (Gunther \& Troftgruken, 1982).

Food prepared in child care feeding programs can be found, or modified, to fill the needs of most handicapped children (Woodburn \& Fitch, 1978). When a food on the regular menu cannot be adapted to the pureed or soft diet, a substitute food of similar nutritive value is needed. The foodservice department should not be expected to always prepare a separate menu, but needs to be provided with menu suggestions of appropriate modifications that meet school lunch requirements (Crump, 1987).

\section{Pureed Foods}

Almost any cooked food can be pureed in a blender; however, in the food preparation area, spicy or gas forming foods are not a good choice for purees (Woodburn \& Fitch, 1978). According to Wellman et al. (1988), foods should be chopped into one inch pieces first, then cooked. Chopping after cooking is often messier. Cooking foods only a short time preserves nutritional value (Wellman et 
Children with Developmental Disabilities

al., 1988). It is recommended that a liquid, such as the cooking liquid, milk, or soup broth, be placed in the blender, in an amount less than or equal to the solid, followed by the chopped foods which are then blended for several seconds to produce the correct smooth texture (Wellman et al., 1988). If the mixture is too thick, additional fluid or blending time may be required. Additional milk, fruit and vegetable juices, broth, and gravies are used to thin purees (Woodburn \& Fitch, 1978). It is more difficult to thicken foods. Some nutritional thickeners are wheat germ, fortified baby cereal, cream of wheat, grated cheese, dry milk powder, yogurt, buttermilk, and other blended foods (Wellman et al., 1988). Purees are thickened by adding instant flake potatoes, dry milk solids, bread products, cooked pasta, or rice according to Woodburn and Fitch (1978). Butter and seasonings will add flavor to puree mixtures.

\section{Intermediate or Soft Foods}

As the child progresses toward ordinary table foods, soft textured foods are offered next. A soft-menu item generally necessitates making only small changes in size or consistency (Gunther \& Troftgruken, 1982). These foods should be small in size, ground or cut fine, and of a single (usually thick) consistency. When planning intermediate foods, it is necessary to think of the effort required to bite, mash, or chew each food to prepare it for swallowing. These foods should be of a consistent thickness with small, soft pieces that are easy to control in the mouth (Woodburn \& Fitch, 1978). A soft food item is not a pureed taco; instead the 
taco meat is mixed with refried beans and sauce, with soft bread served on the side (Gunther \& Troftgruken, 1982). Although the regular and soft food items may often be the same, the staff needs menu suggestions of acceptable substitutions (Gunther \& Troftgruken, 1982).

\section{Liquid Items}

Since thin liquids are difficult for the developmentally delayed child to control, they require thickening (Kosowski \& Sopczyk, 1985). Thickened liquids served in cups encourage drinking; as a result, uncuntrolled behavior of watery liquids in a cup is minimized (Crane, 1987). A thick liquid allows for more reaction time for a child to close the mouth and swallow, whereas a thin liquid does not allow this reaction time (Down, 1990).

Utensil Management

According to Crane (1987), utensil management serves three purposes:

1. It minimizes inappropriate techniques by the feeder (divided and warmed plates influence the feeder to keep the meal divided into different taste islands rather than mixing everything together).

2. It facilitates patterns of eating (particular shapes and sizes of teat, spoon, or feeder lid may either help or hinder the development of new feeding patterns depending upon needs).

3. It facilitates independence (built-up spoon handles, plate guards, nonslip mats, etc. aid the child towards independent feeding). 
Careful selection and use of feeding equipment or utensils advance feeding skills and overcome some problems related to individual handicapping conditions (Crump, 1987). Before choosing any type of specialized adaptive device, an attempt is made to use or adapt regular utensils (Crump, 1987). When adaptive utensils are necessary, several considerations in choosing equipment include:

1. appropriateness to the child's development, as well as chronological age;

2. practicality and ease in cleaning, etc.;

3. cost and replacement if lost or broken; and,

4. for classroom use, compatibility with other classroom equipment. For a child with a poor grasp, the handle of a regular spoon is modified with a plastic tube, foam rubber, or tape. Spoons with curved handles or swivel heads help children who have other types of coordination problems learn to feed themselves (Gunther \& Troftgruken, 1982). Plastic and latex-coated spoons protect the gums from injury when a bite reflex is present (Crump, 1987).

Placing or scooping food onto a spoon or fork presents problems to the handicapped child (Gunther \& Troftgruken, 1982). A bowl or plate with a raised edge or "lip" may help the problem by giving a solid surface on which to push food. Divided dishes keep food separate and maintain color and texture of foods. A dish placed on a wet washcloth as well as raising the dish decreases slipping and spillage (Crump, 1987).

Once the child progresses from a bottle to a cup, poor motor control leads 
to frequent spilling (Crump, 1987). A weighted bottom or a plastic cup with a lid and spout also prevents spilling (Gunther \& Troftgruken, 1982). A "nose cup" is used by children who cannot tilt the head back when drinking (Gunther \& Troftgruken, 1982). A nose cup also allows the feeder to observe the amount of fluid that is consumed by the child (Down, 1990).

Technique Management

Positioning

When feeding a disabled child, the "initial" step is to assist the child into a position that closely approximates a preferred sitting one. Eating in a sitting position promotes safe ingestion of food and enhances the digestion process (Kosowski \& Sopcyzk, 1985). Problems that may interfere with proper positioning include:

1. hypertonic (high) or hypotonic (low) muscle tone,

2. asymmetries,

3. head and neck hyperextension,

4. shoulder elevation and retraction,

5. poor trunk control,

6. posterior pelvic tilt,

7. increased flexor tone of the upper extremities, and

8. increased extensor tone and adduction of the lower extremities

(Shaddix \& Barnacastle, 1986). 
Children with Developmental Disabilities

According to Crump (1987), whether in the classroom or at home, an appropriate chair or seating device should be identified for each child. In general, the child is seated in an upright position for eating (Crump, 1987). The basic position for eating involves placing and supporting the feet flat, the hips and knees at a right angle, and the back straight and supported against the chair (Crump, 1987). A good sitting posture for eating includes:

1. neutral head and neck alignment, with head in midline;

2. stable and relaxed shoulders;

3. symmetrical upper and lower trunk, extended and aligned;

4. neutral and stable pelvis;

5. $90^{\circ}$ flexion for hips, knees, and ankles, with hips slightly abducted; and

6. supported and aligned feet (Shaddix \& Barnacastle, 1986).

\section{Oral/Jaw Control}

Oral control is used to provide jaw stability for use of the tongue, lips, and cheeks. With development and greater jaw control, this process gradually is discontinued (Shaddix \& Barnacastle, 1986). Oral/jaw control techniques are utilized by the feeder during cup drinking, spoon feeding, biting, and chewing. The feeder:

1. sits beside the child and comes from behind with the arm,

2. places the side of middle finger under the chin at the base of the tongue musculature and applies upward pressure, 
3. places the index finger in the depression between the chin and lower lip to assist with opening the mouth,

4. holds the thumb in the palm or away from the face, and,

5. if the child is fed from the front, places the thumb on the chin with the middle or index finger under chin, being careful not to force head and neck hyperextension (Shaddix \& Barnacastle, 1986).

When the child has difficulty drinking from a cup, oral/jaw control is used, and the feeder:

1. places the rim of the cup on the lower lip rather than between the teeth,

2. lifts the cup allowing the liquid just to touch the upper lip,

3. lets the cup remain between the lips after each swallow, and

4. begins cup drinking with a slightly thickened liquid (Shaddix \& Barnacastle, 1986).

For spoon feeding techniques, the feeder:

1. places food on tip of the spoon and presents the spoon horizontally to the center of the lips,

2. places the spoon on the mid portion of the tongue and presses down lightly,

3. slowly removes the spoon and, if necessary, manually closes the lips with fingers, and, 
Children with Developmental Disabilities

4. for tongue thrust, presses the spoon farther back on tongue than normal, presses firmly and slowly removes the spoon (Cervantes, 1990).

\section{Presentation of Food}

Since handicapped children have likes, dislikes, feelings, and sensory preferences, appetizing food items should be just as colorful and appealing as those on the regular menu (Gunther \& Troftgruken, 1982). Wellman et al. (1988) suggested that foods be separated and not mixed together even when mashed. Food that is mashed or pureed is placed on a divided plate to keep food items separate. Foods are also served at a moderate temperature (lukewarm), rather than hot or cold (Kosowski \& Sopcyzk, 1985).

The problems frequently identified in poor feeding technique are the speed of presentation, the excessive amount of food on the spoon, and inappropriate angle of presentation. According to Crane (1987), modifications in feeding techniques are largely a matter of common sense, but the feeder initially requires considerable prompting to develop proper skills particularly when introducing new methods (Crane, 1987).

Parents report that preschool children enjoy meat, cereal grains, baked products, fruit, and sweets. They ask for dairy products, cereal, and snack items such as cookies, crackers, fruit juice, and dry beverage mixes. Preschoolers prefer carbohydrate-rich foods that are easier to masticate than other protein-rich foods (Pipes, 1989). She also reported that preschool children eat and enjoy chicken, 
frankfurters, and hamburger, but refuse more fibrous and harder-to-chew steaks and roasts. Food dislikes include cooked vegetables, mixed dishes, and liver. Children accept raw vegetables better than cooked ones, but often in limited numbers.

Despite reduction in appetite and erratic consumption of food, preschool children enjoy food and gradually increase their average daily energy intakes. If foods that provide a balance of nutrients are presented in a relaxed setting, children will consume an appropriate nutrient intake. Understanding and support from parents and others who offer food to children establish the development of nutritionally sound and satisfying eating practices (Pipes, 1989).

Infants and young children often favor foods because they are offered or because their parents enjoy them. For preschool children, sweetness and familiarity are primary enhancers of choice (Trahms, 1989). Preference rankings by preschool children are highly correlated with consumption...and fear of a new food can be diminished by increasing exposure to the food (Trahms, 1989). It also appears that food preferences of young children are influenced by the adults who provide their food and, thus, their care. According to one study, both mother and father influence a child's food preferences equally, possibly because priority is given to the father's food preferences in the family meal (Trahms, 1989).

\section{The National School Lunch Program}

The National School Lunch Program is a federal assistance program under 
Children with Developmental Disabilities

the child nutrition programs and attempts to meet one-third of the recommended dietary allowances (RDA) per day. The general purpose of the NSLP as stated by the National School Lunch Act is..."to safeguard the health and well-being of the Nation's children and to encourage the domestic consumption of nutritious agricultural commodities and other foods...for the establishment, maintenance, operation, and expansion of nonprofit school lunch programs" (Office of Child Nutrition Services, 1982, p. 43). The Act continues by stating "...participating schools shall serve lunches that are nutritionally adequate, as set forth in these regulations, and shall also coordinate the schools health-education activities with the formation of good eating habits in the lunchroom, to the end that participating children will gain a full understanding of the relationship between proper eating and good health" (Office of Child Nutrition Services, 1982, p. 43).

The National School Lunch Program is the oldest and largest of the child nutrition programs. The program provides payments (reimbursements) to public and private schools for nutritious lunches served to participating children (Office of Child Nutrition Services, 1982). All school lunches which meet the federal guidelines and which are served to eligible children are eligible for reimbursement. There are additional reimbursements for reduced price meals and for free meals (Dutcher, 1990). The charge to the qualified student for reduced price meals shall not exceed $\$ 0.40$ per lunch meal. However, to be eligible for reimbursement, the lunch meals must meet the minimum serving 
Table II

The National School Lunch Program Minimum Requirements

\begin{tabular}{|c|c|c|c|c|c|c|}
\hline & & $\begin{array}{l}\text { Group } 1 \\
\text { age } 1-2 \\
\text { (F }\end{array}$ & $\begin{array}{l}\text { Group II } \\
\text { age 3-4 } \\
\text { chool) }\end{array}$ & $\begin{array}{c}\text { Group ill } \\
\text { age (5-8) } \\
(k-3)\end{array}$ & $\begin{array}{c}\text { Group IV } \\
\text { age } 9 \text { and older } \\
(4-12)\end{array}$ & $\begin{array}{c}\text { Group V } \\
12 \text { yrs \& older } \\
\left(7-12^{2}\right)\end{array}$ \\
\hline Components & & \multicolumn{4}{|c|}{$\begin{array}{l}\text { Minimum } \\
\text { Quantities }\end{array}$} & $\begin{array}{l}\text { Recommended } \\
\text { Quantities }\end{array}$ \\
\hline Mllk & $\begin{array}{l}\text { unflavored, fluid whole, } \\
\text { lowfat skim, or buttermllk } \\
\text { must be offered }\end{array}$ & $\begin{array}{l}\text { 3/4 cup } \\
\text { (6fil. oz.) }\end{array}$ & $\begin{array}{l}3 / 4 \text { cup } \\
\text { (6fl. oz.) }\end{array}$ & $\begin{array}{l}\text { tpint } \\
\text { 8fl. oz.) }\end{array}$ & $\begin{array}{l}\text { tpint } \\
\text { (Eff. oz.) }\end{array}$ & $\begin{array}{l}\text { \& pint } \\
\text { (8fi. oz.) }\end{array}$ \\
\hline & lean meat, pouttry, or fish & $10 z$. & $1 ;$ oz. & $1 \supsetneqq 0 z$. & $2 \mathrm{oz}$ & 3 oz. \\
\hline $\begin{array}{l}\text { Meat or Meat } \\
\text { Alternate }\end{array}$ & $\begin{array}{l}\text { cheese } \\
\text { large egg }\end{array}$ & $10 z$ & $1 \xi 0 z$ & $1 £ 0 z$ & $20 z$ & $\begin{array}{l}302 . \\
1+\end{array}$ \\
\hline (quantity of the & cooked dry beans or peas & cup & $3 / 8$ cup & $3 / 8$ cup & ł cup & $y$ cup \\
\hline $\begin{array}{l}\text { edlble portion } \\
\text { as served) }\end{array}$ & $\begin{array}{l}\text { peanut butter } \\
\text { or an equivalent quantity of } \\
\text { any combination of any of } \\
\text { above }\end{array}$ & 2 Tosp & 3 Tosp & 3 Tosp & 4 TDSD & 6 Tosp \\
\hline $\begin{array}{l}\text { Vegetable } \\
\text { or fruit }\end{array}$ & $\begin{array}{l}2 \text { or more servings or } \\
\text { vegetable or frult or both }\end{array}$ & t Cup & f Cup & $\frac{1}{2}$ cup & \%4 cup & Ya cup \\
\hline $\begin{array}{l}\text { Bread or Bread } \\
\text { Alternate } \\
\text { (servings per } \\
\text { week) }\end{array}$ & $\begin{array}{l}\text { must be enriched or } \\
\text { whale-grain } \\
\text { (at least } \frac{1}{\text { serving }}{ }^{3} \text { for } \\
\text { group I or one serving } \\
\text { groups } 11-V \text { must be served } \\
\text { daily) }\end{array}$ & 5 & 8 & 8 & 8 & 10 \\
\hline
\end{tabular}

Note. ${ }^{1}$ If a school serves another form of milk (whole or unflavored), it must offer its children unflavored fluid lowfat milk, skim milk, or buttermilk as a beverage choice.

${ }^{2}$ The minimum portion sizes for these children are the portion sizes for Group IV.

${ }^{3}$ Serving = 1 slice of bread, or $1 / 2$ cup of rice, macaroni, noodles, other pasta products, other cereal products such as bulgar and corn grits, or as stated in the Food Buying Guide for biscuits, rolls, muffins, and similar products.

From School Nutrition Programs Policy Handbook (p. 31) by Office of Child Nutrition Services, 1982, Sacramento: California State Department of Education. 
Children with Developmental Disabilities

requirements of the NSLP presented in Table II. Also, menu items on the lunch meal must be served to the students to be reimbursable (Dutcher, 1991).

According to Crump (1987), when a food on the regular menu cannot be adapted to the soft diet, a substitute food of similar nutritive value must be provided. Lunch meals with menu item substitutions remain eligible for reimbursement if they meet the minimum serving requirements of the NSLP (Lins, 1991). Furthermore, section 504 of the Rehabilitation Act of 1973 states that "No otherwise qualified handicapped individual in the United States...shall, solely by reason of his handicap, be excluded from the participation in, be denied the benefits of, or be subjected to discrimination under any program or activity receiving federal financial assistance" (Savage, 1977, p. 23). The Rehabilitation Act of 1973 established that school foodservice programs assisted by the United State Department of Agriculture (USDA) were to provide meals for children with special dietary requirements and that those meals were to be provided at no extra cost. However, a medical certificate from a physician must be obtained when a special meal is needed for a handicapped child. The medical certificate should verify that a special meal is needed because of a handicap, prescribe the alternate foods, if needed, and specify the type of texture modification needed to meet the child's special dietary needs. This certificate must be kept on file by the sponsor for each handicapped child served a special meal. A meal requiring any food substitutions or texture modifications is considered a "special meal" (Office of 
Children with Developmental Disabilities

Child Nutrition Services, 1982).

\section{Training Programs}

There is a shortage of personnel qualified to work with preschool children who are handicapped. The shortage of educational professionals is exacerbated by the fact that many related service personnel are not trained to work with this population (Congressional Report, 1985). In 1986, a questionnaire was sent to special education directors in the state of Virginia to examine the nutrition services and programs available for handicapped and chronically ill school children. According to Horsley and Allen (1989), the survey identified the need for increased training and support for school personnel to make nutrition services better integrated into the school curriculum for students with special health care needs.

There is a need to establish comprehensive systems of development by providing inservice training to staff already working with preschool handicapped children, to collaborate with universities to strengthen programs to prepare newly qualified professionals, and to establish certification requirements (Congressional Report, 1985). The American Dietetic Association Position Statement (1989) made two recommendations regarding training given to future professionals in this area:

1. Principles of care for children with special health care needs and clinical nutrition experiences in interdisciplinary settings should be incorporated 
Children with Developmental Disabilities

into the curriculum of undergraduate and graduate nutrition programs, dietetic internships, and Applied Preprofessional Practice Programs (AP4).

2. Completion of a nutrition traineeship, fellowship, or other specified nutrition training program should be required of dietitians taking leadership positions in services for this population of children.

\section{Liability Issues}

When compared to adults and older children, children under five years are at a higher risk for asphyxiation (choking or suffocating) caused by food (McClannahan, 1987). Death from food asphyxiation was reported in 102 children within a two-year period, and most were less than two years of age. Children can choke on almost any food and are more likely to have trouble with hard and slippery foods which can plug the throat and thick, sticky foods which line the back of the throat (Pipes, 1989). Prevention is the most reasonable approach to childhood choking (Pipes, 1989). It is recommended that children be supervised while eating. In addition, caregivers need to learn emergency intervention to rescue a child from choking or suffocation (McClannahan, 1987).

According to Towery (1990), if a child were to choke and die, a case could be presented. For the purpose of this research paper, legal definitions need to be established:

1. Damages: The measure of injury, physical, mental, and emotional, as a result of another's action or omission, whether such action or omission be 
intentional or negligent. Injury is what is actually suffered, while damage is the measure of compensation for such suffering (Black, 1979).

2. Liable: Bound or obliged in law or equity, responsible, chargeable, answerable, compelled to make satisfaction, compensation, or restitution (Black, 1979).

3. Negligence: Negligence is the failure to use such care as a reasonably prudent and careful person would use under similar circumstances; it is the doing of some act which a person of ordinary prudence would not have done under similar circumstances or failure to do what a person of ordinary prudence would have done under similar circumstances (Black, 1979).

This case could be dealt with by the general principles of negligence (Towery, 1990). Negligence must first be proven by the court, such as an improper diet order or lack of attention to the child (Rabel, 1990). There would be expert testimony stating the standard of care expected for this particular population would be. The injured party's family would supply evidence showing the assessed special needs of the child and state that the school dealing with this population of children should have known how to provide appropriate care for their child (Towery, 1990). The school would supply evidence showing that they have training programs for the staff and that their standard is consistent with training in schools. If training programs are not available for teachers and foodservice workers, the school would supply evidence that, in all the school districts in the 
Children with Developmental Disabilities

county, there are no training programs and that they were operating at the standard of care for all districts. The injured party's family would state that a reasonable person would have known that the action could cause possible injury to the child and that training was needed and should have been given (Towery, 1990). If negligence is proven, anyone could be liable (Rabel, 1990). The damages assessed for a person with a handicap, such as the profoundly disabled, are less than that for a "normal" child because the expected contribution to society is less (Rabel, 1990). It is a difficult issue; the children must be fed to prevent death. However, the child may die from choking on the food due to the inherent eating disorder (Rabel, 1990). Examples of questions addressed in assessing the potential for liability include:

1. Has the agency or staff acted in a reasonable manner?

2. Has good judgement been used?

3. Have precautions been taken to minimize something like this from happening?

4. Have staff received training in the care of handicapped children?

5. What is the history of the agency? Have other children been injured under similar circumstances (Balakshin, 1990)? 
CHAPTER 2

JOURNAL ARTICLE 
Authors Title Page

\section{EVALUATION OF THE REIMBURSABLE MEAL SERVED TO STUDENTS}

WITH PROFOUNDLY DISABLING CONDITIONS

Joan Giampaoli, M.S. Graduate Student

Department of Nutrition and Food Science, San Jose State University

Home Address: 1294 Hanchett Avenue, San Jose, CA 95126

Home Phone: (408/295-9485)

${ }^{1}$ Elveda Smith, Ph.D., Professor

Department of Nutrition and Food Science, San Jose State University

1 Washington Square, San Jose, CA 95192

(408/924-3110)

Julianne K. Dutcher, M.S.,R.D., Associate Professor

Department of Nutrition and Food Science, San Jose State University

1 Washington Square, San Jose, CA 95192

(408/924-3107)

Amy Lins, R.D., Food Service Director

San Jose Unified School District

250 Stockton Avenue, San Jose, Ca 95126

(408/998-6021)

Janet Cervantes, O.T.R.

East Valley Center

355 North 33rd St., San Jose, CA 95133

(408/729-3900)

Panfilo Belo, Ph.D., Associate Professor

Department of Nutrition and Food Science, San Jose State University

1 Washington Square, San Jose, CA 95192

(408/924-3108) 
EVALUATION OF THE REIMBURSABLE MEAL SERVED TO STUDENTS WITH PROFOUNDLY DISABLING CONDITIONS

\author{
ABSTRACT \\ An evaluation study was conducted to determine whether lunch meals \\ served at a special education school site met the minimum requirements of the \\ National School Lunch Program (NSLP) and to determine the percentage of \\ menu items served to children with profoundly disabling conditions. Evaluation of \\ lunch meals served to 24 profoundly disabled students was conducted for 20 \\ school days. Data on serving sizes indicted no significant difference between \\ portions served to the younger students (ages 5-8) in Classroom I and the NSLP \\ requirements. Serving sizes for the older students (ages 9 and older) in \\ Classrooms II and III differed from those of the NSLP, specifically in the meat \\ and fruit/vegetable groups. Menu items that were texturally modified and served \\ to the students varied between classrooms in the meat and fruit/vegetable food \\ groups. Milk was generally not served due to its possible mucous-producing \\ effects. Other menu items were not served due to the possibility of choking. \\ Therefore, serving sizes as well as foods considered appropriate to modify and \\ serve to students with profound disabilities were inconsistent. Key words: \\ evaluation; National School Lunch Program; disabling conditions; texturally \\ modified; choking; appropriate.
}




\section{INTRODUCTION}

Public Law 94-142 (PL 94-142), called the Education for All Handicapped Children Act of 1975, mandates that handicapped children, ages three through twenty-one years, are entitled to an education in the least restrictive environment (Gunther and Troftgruken, 1982). An amendment to the Rehabilitation Act of 1973 (Public Law 93-112) established that school foodservice programs assisted by the United States Department of Agriculture (USDA) were to provide meals for children with special dietary requirements and that those meals were to be provided at no extra cost (United States Code, 1973). As a result of this legislation, many handicapped children are enrolled in public schools and are participating in the National School Lunch and School Breakfast Programs (Horsley and Allen, 1989).

The National School Lunch Act stipulates a meal pattern that the schools must follow to receive reimbursement of meals served to all children including handicapped children (Gunther and Troftgruken, 1982). Improvement in the overall nutrition of school children is the goal of school foodservice. National School Lunch and Breakfast Programs contribute by offering meals of nutritious foods, based on the four major food groups, which are well-prepared and served (Woodburn and Fitch, 1970). If the state and federal requirements for these meals are met, the meals are claimed for reimbursement from the Child Nutrition Program through the State Agency (Gunther and Troftgruken, 1982). 
Adequate nutrition is essential for the growth and health of a handicapped child and may be the most important factor in the survival of some of these children (Caldwell, 1982). According to The American Dietetic Association Position Statement (ADAPS) (1989), optimal nutrition is essential for children to achieve their physical and developmental potential. However, Dietz and Bandini (1989) reported that energy intakes of developmentally delayed children were generally lower than the age-matched controls. Children who consume inadequate calories are at risk for a number of problems, including malnutrition (Riordan Et al., 1984). According to Connor Et al. (1987), many reasons are cited to explain why developmentally delayed children are prone to undernourishment and malnutrition, including difficulty in sucking and/or swallowing, hyperactivity, or weakness resulting in poor intake of food. Ineffective parenting also contributes to this problem. The development of poor eating behavior is encountered frequently among students in special education programs (Crump, 1987). She also cited other reasons for malnutrition in handicapped children, including lack of nutrition education resulting in poor food choices and school lunches that do not provide foods which the children can eat.

Despite improvements in meeting their complex needs, major gaps in services exist, particularly those related to nutritional support, a crucial factor needed for developmentally disabled children to achieve their maximum potential (ADAPS, 1989). Therefore, a need exists to determine whether lunch meals 
served to children with profoundly disabling conditions meet their unique nutritional requirements. The purposes of this study were to evaluate the following questions:

1. Do lunch meals served at a special education school meet the minimum requirements of the National School Lunch Program?

2. Do menu items on the lunch meal require textural modification?

3. What percentage of menu items offered on the lunch meal are served to children with profoundly disabling conditions?

\section{METHODS AND MATERIALS}

\section{Subjects}

The study was conducted at a special education school on a special education school site by the Santa Clara County Superintendent of Schools in Santa Clara County, CA. The school educates children with severe and profoundly disabling conditions. A population of 24 children ages 5-18 were the subjects; all had profound mental and physical disabilities (Table 1). The disabling conditions ranged from cerebral palsy and seizure disorders to pre- or postnatal injuries of unknown etiology for which no clear diagnosis had been made. Subject selection was based on students who had profoundly disabling conditions, were immobile without assistance, and required textural modification of food. The female to male ratio was 11:13. Two of the 24 children in Classroom III were "self-feeders" who consumed chopped food by picking up the 
food items and feeding themselves. The others required pureed or coarsely ground foods and were not "self-feeders." The subjects were divided into Classrooms I, II, and III based on age and according to the NSLP serving requirements. Seventeen $(71 \%)$ of the subjects received lunch meals at a reduced cost or free. Seven $(29 \%)$ received lunch meals at the standard price.

According to the Office of Child Nutrition Services (1982), "a child is defined as a person under 21 years of age who is enrolled in a high school grade or under or is a resident of a residential child care institution. The definition also includes persons, regardless of age, who are mentally or physically handicapped and who are enrolled in a non-residential public or non-profit private school of high school grade or under which participates in the National School Lunch Program, or Special Milk Program" (p. 8).

\section{National School Lunch Program Requirements}

The minimum serving requirements for Classrooms I, II, and III according to the NSLP minimum requirements are: $11 / 2$ ounces meat/meat alternate for Classroom I and 2 ounces for Classrooms II and III; 8 servings per week from bread/bread alternate group for the three classrooms; $1 / 2$ cup fruit or vegetable for Classroom I and 3/4 cup for Classrooms II and III; and 8 ounces fluid milk for the three classrooms.

The NSLP specifies restrictions for meeting these requirements; these were used in this study and are: 
1. Enriched and protein-fortified macaroni products may be used for either part for the meat/meat alternate or the bread/bread alternate but not both in the same meal. Such products cannot meet more than $50 \%$ of the meat or meat alternate requirements.

2. Two forms of the same vegetable or fruit such as oranges and orange juice cannot be served in the same meal and be counted as the total vegetable/fruit requirement.

3. Fruit and vegetable juices are eligible to meet $50 \%$ of the fruit/vegetable meal requirement if the product label indicates that it is a full strength or $100 \%$ juice.

4. Cooked dry beans or peas may be used as a meal alternate or as a vegetable but not as both in the same meal (Office of Child Nutrition Services, 1982).

\section{Data Collection Method}

The method of data collection was a food frequency checklist modified from the Food Group Evaluation form adapted from Krause and Mahan (1984) based on the Basic Four Food Groups. Two parameters were evaluated. The first was for subjects age 5-8 and 9 and older to determine whether lunch meals served met the minimum requirements of the NSLP. Data were then collected regarding the textural modification of menu items and the foods served to the subjects per food group. 
Comparison of Lunch Meals Served to the NSLP Requirements

To evaluate whether the lunch meals met the minimum requirements of the NSLP, a random lunch sample was collected for 20 school days, weighed to the nearest gm, and divided by $28.4 \mathrm{gm}$ to determine the weight of the menu items in ounces. Ounces were converted to standard measurements as necessary based on the food buying guide (USDA, 1983). Menu items that met the minimum requirements of serving sizes were tallied on the food frequency checklist and received 1 point for "yes" the menu items met the minimum requirements of the NSLP. Menu items that did not meet the minimum requirements for serving sizes received 0 points for "no."

Textural Modification of Menu Items

Textural modification of menu items was observed to determine the portion of the lunch meal which required textural modification vs those menu items which were texturally modified. The criteria established to determine whether a menu needed modification was based on the texture of the food prior to modification. Foods which were of a soft consistency, such as a pudding or applesauce and liquid items, did not require modification. Menu items that were not of a soft consistency were considered necessary to modify prior to being served. Menu items that required textural modification but were not modified were assigned 0 points for "no" the menu item was not modified. Menu items that were texturally modified received 1 point for "yes" the menu item was modified. 
If $100 \%$ of the menu items within a food group were not modified for a lunch meal, the food group received 0 points.

Menu Items Served

The percentage of menu items served was determined for a period of 20 school days. Menu items served to $100 \%$ of the subjects were assigned 1 point per student and converted to percents. Menu items not served to any of the subjects received 0 point. Menu items served is defined as the food items that were modified and presented to the student for consumption. It does not include menu items actually consumed by the students.

\section{RESULTS AND DISCUSSION}

\section{Comparison of Lunch Meals Served to the NSLP Requirements}

Results for Classrooms I, II, and III in relation to meeting the minimum requirements of the NSLP are presented in Table 2 . The meals satisfactorily met the minimum requirements of the NSLP in all food groups for Classroom I (ages 5-8). However, for Classrooms II and III, requirements for meat group foods were met $75 \%$ of the time and $50 \%$ of the time for fruit/vegetable group foods. Within the meat group, however, on several days the serving size exceeded the 2 oz. requirement, so the average serving for this group met the requirement for Classrooms II and III for the 20-day period. The fruit/vegetable group did not meet the NSLP serving requirements 10 of the 20 days (50\%) for Classrooms II and III. Upon evaluating this discrepancy, it was found that the wrong scoop size 
was being used by foodservice workers to portion the fruit/vegetable menu items. According to the NSLP guidelines, serving requirements are to be based on either age/grade level for children. If this is not possible, then serving requirements are to be based on Group IV serving sizes, ages 9 and older, which is $3 / 4$ cup (Office of Child Nutrition Services, 1982).

\section{Textural Modification of Menu Items}

Data on the textural modification of menu items are presented in Table 3. According to the researchers, foods in the meat and bread groups required textural modification $100 \%$ of the time, whereas the fruit/vegetable group needed textural modification $90 \%$ of the time due to the exclusion of applesauce and orange juice. Since the milk items are fluid, no textural modification was required within this food group.

Menu items within food groups that were actually modified differed between Classrooms I, II, and III. Menu items within the meat and bread groups for Classrooms I and II were not modified $100 \%$ of the time as in Classroom III, because certain menu items were not considered appropriate to modify such as bean burritos, cheese pizza, and taco shells. These foods tended to become thick and too gummy or coarse when modified. Even so, menu items considered appropriate to modify varied between these two classrooms. Also, menu items in the meat group that were not modified often affected the percentage of menu items that were not modified in the bread group, such as the beans and the 
tortilla for the bean burrito. These menu items were considered appropriate to modify by coarsely chopping the menu item for the two "self-feeders" in Classroom III.

The fruit/vegetable group showed the greatest variation between the three classrooms. The staff in classrooms I and II felt menu items which upon pureeing would become stringy or contain hard particles, such as celery, corn, oranges, etc., would not be appropriate to modify for the subjects. These menu items were served frequently over the 20-day school period, which decreased the amount of texturally modified foods for the fruit/vegetable group. Classroom III, in contrast, felt that these menu items were appropriate to modify, with the exception of oranges and grapes. The percentage of textural modification was also decreased for all three classrooms since the applesauce and orange juice did not require modification on the days which they were served. For the two "self-feeders," the celery was not considered appropriate to coarsely chop because the texture is too hard for the students to chew and swallow safely.

Textural modification of lunch meals was observed to determine whether lunch meals were modified in bulk or individually for each student and then portioned and whether the menu items were modified individually or in bulk. The method of textural modification was similar for all classrooms. Lunch meals were delivered to the classrooms unmodified in individual portions. A staff member in each classroom prepared and served the food. Lunch items for all 
students, except the "self-feeders," were combined and modified together in bulk in a food processor and then portioned. For example, the meat, bread alternate, and vegetable items (except for salad) were combined and modified together. The fruit items were modified separately. In contrast, Wellman Et al. (1988) suggested that foods be separated and not mixed together even when mashed. They recommended that mashed or pureed foods should be placed on a divided plate to keep food items separated. In addition, it was observed that textural modification was done the day prior to serving the food. The food was stored under refrigeration, re-heated and served.

\section{Menu Items Served}

Data on the percentage of menu items served are presented in Table 3. The percentage of menu items served was directly affected by the percentage of menu items texturally modified from the meat and bread groups. The percentage of menu items texturally modified was equivalent to the percentage of menu items served for all three classrooms. This differed for the fruit/vegetable group. For Classrooms I and II, the percentage of menu items served exceeded the percentage of menu items which were texturally modified. This is attributed to the fact that the orange juice and applesauce were served, requiring no modification. For Classroom III, the percentage of menu items which were texturally modified exceeded the percentage of menu items served. This is due to the fact that the "self-feeders" were not served lettuce, celery, and carrots in 
addition to the other menu items that were not considered appropriate to texturally modify and serve. Therefore, these three menu items were texturally modified and served to the students who needed assistance in eating, but they were not served to the "self-feeders." It was felt by the staff that these foods were too hard and coarse to serve to these two students. Within the milk group, only 1 student (10\%) in Classroom III was served milk. Students in Classrooms I and II were never served milk. However, it was occasionally used to thin purees during textural modification. The explanation given by the staff for omitting milk was the concern regarding mucous production and respiratory problems.

Since no clear guidelines were given as to the foods appropriate to modify and serve, the choice of menu items that were modified and served varied among staff members for Classrooms I, II, and III, particularly in the fruit/vegetable group. Food items not utilized were substituted with another food item such as canned vegetables and pureed baby meats. However, these substitute food items were purchased with the teacher or aide's personal money.

The primary reason that a food was not modified and/or served was the fear that the subjects would choke. Additionally, foods to which a student was allergic were eliminated from that student's lunch meal. The staff decided that food items which upon pureeing, formed a sticky, gummy, or stringy mass, contained hard particles, or had a coarse texture, were inappropriate to modify and serve. McClannahan (1987) stated that foods which are highly viscous (thick 
and sticky) and hard or tough cause the most hazard to young children.

From this study, the amount of food actually served to the subjects was less than that provided although the objective was not to study actual food intake for children ages 5-8 and 9 and older. Crump (1987) stated that malnutrition in handicapped children may be caused by the development of poor eating behavior. Although the menu items generally met the NSLP minimum requirements, some foods were judged inappropriate to modify and serve due to choking problems or mucous production and were therefore not served. Dietz and Bandini (1989) reported that energy intakes of developmentally delayed children are generally lower than age-matched controls. According to the ADAPS (1989), optimal nutrition is essential for children to achieve their physical and developmental potential; however, major gaps still exist in service for developmentally delayed children, particularly those related to nutritional support.

\section{CONCLUSION}

Data on the evaluation of menu items indicated that subjects in Classrooms II and III were not served lunch meals that met the minimum requirements of the NSLP for the meat and fruit/vegetable groups. No deviation in the serving sizes for Classroom I lunch meals from those of the NSLP was observed. Decisions regarding the textural modification of foods and foods actually served were at the discretion of the classroom staff. The primary reasons for omitting menu items were the possible fear of choking and mucous formation. Foods considered 
appropriate to serve varied between the three classrooms. The researchers recommended that communication between the foodservice director, foodservice workers, classroom staff, parents, and the students' physicians is needed. In addition, the delivery of already modified and portioned food for each child needs to be evaluated. Finally, consent needs to be obtained from the parents and physicians and detailed diet prescriptions obtained from the physicians of the children to permit food substitutions on the lunch meal and, therefore, appropriate foods. 


\section{NOTES}

${ }^{1}$ Address all correspondence to Dr. Elveda Smith, Department of Nutrition and Food Science, San Jose State University, 1 Washington Square, San Jose, CA 95192. 


\section{ACKNOWLEDGEMENTS}

This study was conducted in partial fulfillment for the degree Master of Science in Nutritional Science through the Department of Nutrition and Food Science at San Jose State University, 1 Washington Square, San Jose, CA 95192. 


\section{REFERENCES}

AMERICAN DIETETIC ASSOCIATION POSITION STATEMENT. 1989.

Nutrition services for children with special health care needs, J. Am. Diet. Assoc. 23, 1133-1137.

CALDWELL, M. 1982. Nutrition services for handicapped child, Pub. Health Rep. 97, 483-485.

CONNOR, F.P., WILLIAMSON. G. G. and SIEPP, J.M. 1987. Program Guide for Infants and Toddlers with Neuro-Motor and Other Developmental Disabilities, Teachers College Press, New York.

CRUMP, I.M. 1987. Nutrition and Feeding of the Handicapped Child, Little Brown \& Company, Boston.

DIETZ, W.H. and BANDINI, L. 1989. Nutritional assessment of the handicapped child, Ped. in Rev. 11, 109-114.

GUNTHER, M.L. and TROFTGRUKEN, J.A. 1982. School Nutrition and Food Service Techniques for Children with Exceptional Needs, Ca. State Dept. of Ed., Sacramento.

HORSLEY, J.S. and ALLEN E.R. 1989. Expanding nutrition services for handicapped children, Sch. Food Ser. Jour. 54, 44.

KRAUSE, M.V. and MAHAN, L.K. 1984. Food, Nutrition and Diet Therapy, W.B. Saunders Company, Philadelphia.

MCCLANNAHAN, C. 1987. Feed and Caring for Infants and Children with 
Special Needs, Natl. Agr. Lib., Beltsville, MD.

OFFICE OF CHILD NUTRITION SERVICES. 1982. School Nutrition Programs

Policy Handbook, Ca. State Dept. of Ed., Sacramento.

RIORDAN, N.M., IWATE, B.A., FINNEY, J.W., WOHL, M.K. and STANLEY, A.E. 1984. Behavioral assessment and treatment of chronic food refusal in handicapped children, J. App. Behav. Anal. 17, 327-341.

UNITED STATES DEPARTMENT OF AGRICULTURE. 1983. Food Buying

Guide for Child Nutrition Programs, Ca. State Dept. of Ed., Sacramento.

UNITED STATES CODE. 1973. Public Law 93-112: Rehabilitation Act., U.S.

Fed. Gov., Washington, DC.

WELLMAN, N.S., RARBACK, S., BASCH, L.G. and SIMONS, S.B. 1988.

Nutrition and Handicapped Children: A Handbook for Parents and Teachers,

Dept. of Ed. and Florida Inter. Univ., Miami.

WOODBURN, J.M. and FITCH, M.M. 1978. Feeding Programs and Handicapped Child, Wa. Assoc. Ret. Citiz. Trust Fund, Seattle. 
TABLE 1

DEMOGRAPHIC DATA ON SUBJECTS

\begin{tabular}{lccc}
\hline Classroom Studied & $\begin{array}{c}\text { Number of } \\
\text { Subjects }\end{array}$ & Age Range & Sex \\
& 5 & $3-7$ & $3: 2$ \\
\hline Classroom I & 9 & $8-14$ & $5: 4$ \\
Classroom II & 10 & $15-21$ & $5: 5$ \\
Classroom III & & & \\
\hline
\end{tabular}


TABLE 2

LUNCH MEALS SERVED THAT MET THE NATIONAL SCHOOL

LUNCH PROGRAM MINIMUM REQUIREMENTS

\begin{tabular}{|c|c|c|c|c|c|}
\hline \multirow{4}{*}{$\begin{array}{l}\text { Classroom } \\
\text { Studied }\end{array}$} & \multirow{4}{*}{$\begin{array}{l}\text { Number of } \\
\text { Meals } \\
\text { Served }\end{array}$} & \multirow{2}{*}{\multicolumn{4}{|c|}{$\begin{array}{l}\text { Meals meeting NSLP Minimum Requirements } \\
\text { by Food Groups }(\%)^{\mathrm{a}}\end{array}$}} \\
\hline & & & & & \\
\hline & & \multirow{2}{*}{$\begin{array}{l}\text { Meat/Meat } \\
\text { Alternate }\end{array}$} & \multirow{2}{*}{$\begin{array}{l}\text { Bread/Bread } \\
\text { Alternate }\end{array}$} & \multirow{2}{*}{$\begin{array}{l}\text { Fruit/ } \\
\text { Vegetable }\end{array}$} & \multirow[t]{2}{*}{ Milk } \\
\hline & & & & & \\
\hline Classroom I & 100 & $95(95)$ & $100(100)$ & $100(100)$ & $100(100)$ \\
\hline Classroom II & 180 & $153(85)$ & $180(100)$ & $90 \quad(50)$ & $180(100)$ \\
\hline Classroom III & 200 & $170(85)$ & $200(100)$ & $100 \quad(50)$ & $200(100)$ \\
\hline
\end{tabular}

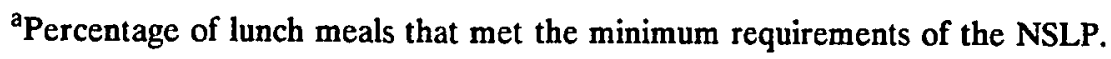


TABLE 3

TEXTURAL MODIFICATION OF MENU ITEMS AND

MENU ITEMS SERVED

\begin{tabular}{|c|c|c|c|c|c|}
\hline Classroom & Number & & & Food Groups & \\
\hline \multirow{2}{*}{ Studied } & or Meals & & Meat/Meat & & Fruit/ \\
\hline & & & $\%$ & $\%$ & $\%$ \\
\hline \multirow[t]{3}{*}{ Classroom I } & 100 & needed mod. ${ }^{a}$ & 100 & 100 & 90 \\
\hline & & was mod. ${ }^{b}$ & 85 & 80 & 45 \\
\hline & & actually served & 85 & 80 & 45 \\
\hline \multirow[t]{3}{*}{ Classroom II } & 180 & needed mod. ${ }^{a}$ & 100 & 100 & 90 \\
\hline & & was mod. ${ }^{\mathrm{b}}$ & 75 & 70 & 40 \\
\hline & & actually served & 75 & 70 & 45 \\
\hline \multirow[t]{3}{*}{ Classroom III } & 200 & needed mod. ${ }^{a}$ & 100 & 100 & 90 \\
\hline & & was mod. ${ }^{b}$ & 100 & 100 & 72 \\
\hline & & actually served & 100 & 100 & 68 \\
\hline
\end{tabular}

${ }^{a}$ Foods needing modification

${ }^{b}$ Foods that were modified 
Children with Developmental Disabilities

\section{CHAPTER 3}

\section{SUMMARY, LIMITATIONS, RECOMMENDATIONS}

Summary

Historically, children with developmental disabilities did not survive; however, technological advancements and improvements in medical care have increased the survival rates of these children. With an increase in this population, more of these children are entering the public education system as mandated by Public Law 94-142 and are eligible to receive the reimbursable meal. However, reimbursement from the child nutrition program requires that meals which are served meet the minimum requirements of the NSLP and that menu items on the lunch meal be served to the recipients (Dutcher, 1991).

Children with developmental disabilities are at an added disadvantage in their ability to consume foods. Neurological deficits disrupt the oral/motor mechanism, and these children have difficulty chewing and swallowing foods. When menu items offered on the lunch meal are not served, nutritional deficits are encouraged. The child with a developmental disability is at a greater risk for lowered energy intake levels than the "normal" child but is equally dependent on proper nutrition for growth, development, and survival (Caldwell, 1982; Dietz \& Bandini, 1989).

Limited research is available regarding the NSLP and children with developmental disabilities. This study evaluated whether lunch meals served met 
the NSLP minimum requirements. In addition, the need to texturally modify menu items as well as those items served was also evaluated. The results indicated that, with the exception of the fruit/vegetable group, the lunch meals met the minimum requirements of the NSLP. However, the decision regarding menu items that were appropriate to modify and serve to the subjects was arbitrary. It was concluded that communication between the foodservice director, foodservice workers, classroom staff, parents, and the students' physicians is needed. Additionally, it was concluded that special meals with appropriate menu item substitutions need to be provided for children with profoundly disabling conditions.

\section{Limitations}

In concluding this study, several limitations were identified and include:

1. No attempt was made to evaluate actual food intake; therefore, it was not possible to determine whether a menu item was not accepted due to dislike, inappropriate temperature, or lack of appetite.

2. Menu items were usually modified together.

3. The sample size was small, and it is not possible to generalize the data.

\section{Recommendations}

It is recommended that:

1. communication between the foodservice director, foodservice workers, classroom staff of the children with profoundly disabling conditions, parents and 
Children with Developmental Disabilities

physicians be instituted;

2. detailed dietary prescriptions be obtained as necessary from the subjects' physicians;

3. with diet prescriptions, appropriate food substitutions on the lunch meal be provided;

4. the use of the milk group be investigated as directed by the subject's physician;

5. menu items be modified individually and portioned separately by the foodservice staff and delivered to the special education site;

6. the procurement and use of infant/junior foods be studied to facilitate the preparation and service of food by the foodservice staff. 
Children with Developmental Disabilities

\section{REFERENCES}

Alakija, W. (1988). Nutrition services for the handicapped child. Public Health Reports, 97(5), 483-485.

American Dietetic Association Position Statement. (1981). Infant and child nutrition: Concerns regarding the developmentally disabled. Journal of the American Dietetic Association, 78, 443-450.

American Dietetic Association Position Statement. (1989). Nutrition services for children with special health care needs. Journal of the American Dietetic Association, 23(8), 1133-1137.

Balakshin, M. (1990, July). Personal communication.

Blacher, J. (1984). A dynamic perspective on the impact of a severely handicapped child on the family. In J. Blacher (Ed.), Severely handicapped young children and their families (pp. 3-43). Oriando, FL: Academia Press, Inc.

Black, H. C. (1979). Black's law dictionary (5th ed.). St. Paul, MN: West Publishing Co.

Caldwell, M. (1982). Nutrition services for the handicapped child. Public Health Reports, 97(5), 483-485.

Caliendo, M. A., Booth, G., \& Moser, P. (1982). Iron intakes and serum ferritin levels in developmentally delayed children. Journal of the American Dietetic Association, 81, 401-406. 
Children with Developmental Disabilities

Cervantes, J. (1990, November). Personal communication.

Congressional Report. (1985). Seventh annual report to Congress on the implementation of the education of the handicapped act. Washington, DC: U. S. Congress

Connor, F. P., Williamson, G. G., \& Siepp, J. M. (1987). Program guide for infants and toddlers with neuro-motor and other developmental disabilities. New York: Teachers College Press.

Crane, S. (1987). Feeding the handicapped child: A review of intervention strategies. Birmingham, AL: AB Academic Publishers.

Crump, I. M. (1987). Conditions that require special dietary management. In I. M. Crump (Ed.), Nutrition and feeding of the handicapped child (pp. 71-74). Boston: Little Brown \& Company.

Danielson, A., \& Bellomy, F. (1988). State variations in placement of children with handicapped in segregated environments. Washington, DC: Office of Special Education Programs.

Dietz, W. H., \& Bandini, L. (1989). Nutritional assessment of the handicapped child. Pediatrics in Review, 11(4), 109-114.

Down, J. (1990, November). Personal communication.

Dutcher, J. (1991, March). Personal communication.

Gearheart, B. R., \& Weishahn, M. W. (1980). The handicapped student in the regular classroom. St. Louis: C. V. Mosby. 
Children with̉ Developmental Disabilities

Gunther, M. L., \& Troftgruken, J. A. (1982). School nutrition and food service techniques for children with exceptional needs. Sacramento: California State Department of Education.

Horsley, J. S., \& Allen, E. R. (1989). Expanding nutrition services for handicapped children. School Food Service Journal, 54(7), 44.

Horsley, J. S., Allen, E. R., \& White, P. A. (1990). Nutrition management of the handicapped and chronically ill school age children. Beltsville, MD: Virginia Department of Health and Virginia Department of Education.

Howard, R. B. (1981). Nutritional support of the developmentally disabled child.

In R. M. Suskind (Ed.), Textbook of pediatric nutrition (pp. 577-582). New York: Raven Press.

Johnson, S. (1990, August). Personal communication.

Kalisz, K. A., \& Ekvall, S. (1984). A nutrition interview for clients with developmental disorders. Mental Retardation, 22(6), 279-288.

Kosowski, M. M., \& Sopcyzk, D. L. (1985). Feeding hospitalized children with developmental disabilities. MCN, 10, 190-194.

Krause, M. V., \& Mahan, L. K. (1984). Food, nutrition and diet therapy. Philadelphia: W. B. Saunders Company.

Lins, A. (1991, May). Personal communication.

Lucas, B. L. (1989). Serving infants and children with special health care needs in the 1990s: Are we ready? Journal of the American Dietetic Association, 
Children with Developmental Disabilities

89(11), 1599-1605.

McClannahan, C. (1987). Feeding and caring for infants and children with special needs. Beltsville, MD: National Agricultural Library.

Morris, M. J., Ingram, D. H., Howison, M., Kaltreidor, K., \& Nichter, C. A. (1990). The disabled child. In D. J. Gines (Ed.), Nutrition management in rehabilitation (pp. 109-140). Rockville, MD: Aspen Publishers, Inc.

Office of Child Nutrition Services. (1982). School nutrition programs policy handbook. Sacramento: California State Department of Education. Percy, S. L. (1989). Disability, civil rights, and public policy. Tuscaloosa, AL: University of Alabama Press.

Pipes, P. L. (1989). Between infancy and adolescence. In P. L. Pipes (Ed.), Nutrition in infancy and childhood (pp. 120-142). St. Louis: C. V. Mosby, Co.

Pipes, P. L., \& Glass, R. P. (1989). Nutrition and feeding of children with developmental delay and related problems. In P. L. Pipes (Ed.), Nutrition in infancy and childhood (pp. 361-386). St. Louis: C. V. Mosby, Co.

Rabel, A. (1990, June). Personal communication.

Ray, L. (1991, January). Personal communication.

Riordan, M. M., Iwate, B. A., Finney, J. W., Wohl, M. K., \& Stanley, A. E. (1984). Behavioral assessment and treatment of chronic food refusal in handicapped children. Journal of Applied Behavioral Analysis, 17, 327-341. 
Children with Developmental Disabilities

Savage, D. G. (1977). Educating all the handicapped. Arlington, VA: National School Public Relations Association.

Savage, D. G. (1981). Handicapped infants and preschool children: Program guidelines. Sacramento: California State Department of Education.

Shaddix, T., \& Barnacastle, N. (1986). Nutritional care for the child with developmental disabilities. Birmingham, AL: United Cerebral Palsy of Alabama.

Stainback, W., Stainback, S., \& Bunch, G. (1989). Introduction and historical background. I. W. Stainback, S. Stainback, \& M. Forest (Eds.), Educating all students in the mainstream of regular education (pp. 3-14). Baltimore: Paul H. Brookes Publishing.

Towery, J. (1990, July). Personal communication.

Trahms, C. M. (1989). Factors that shape food patterns in young children. In P. L. Pipes (Ed.)., Nutrition in infancy and childhood (pp. 160-170). St. Louis: C. V. Mosby, Co.

United States Code. (1973). Public Law 93-112: Rehabilitation Act. Washington, DC: U.S. Federal Government.

United States Code. (1975). Public law 94-142: Education of all handicapped children act. Washington, DC: U. S. Federal Government.

United States Department of Agriculture. (1983). Food Buying guide for child nutrition programs. Sacramento, CA: California State Department of 
Children with Developmental Disabilities

Education.

Wehman, P., Renzaglia, A., \& Bates, P. (1985). Fundamental living skills for moderately and severely handicapped individuals. Austin, TX: Pro-Ed.

Wellman, N. S., Rarback, S., Basch, L. G., \& Simons, S. B. (1988). Nutrition and handicapped children: A handbook for parents and teachers. Miami:

Department of Education and Florida International University.

Wood, J. W. (1989). Mainstreaming: A practical approach for teachers. Columbus, OH: Murrill Publishing.

Woodburn, J. M., \& Fitch, M. M. (1978). Feeding programs and the handicapped child. Seattle: Washington Association for the Retarded Citizen Trust Fund. 